\title{
"Quantitative study of selected Facebook marketing communication engagement factors in the optics of different post types"
}

\begin{tabular}{|c|c|}
\hline AUTHORS & $\begin{array}{l}\text { L'udovit Nastišin (D https://orcid.org/0000-0002-4403-7580 } \\
\text { Richard Fedorko (D https://orcid.org/0000-0003-3520-1921 } \\
\text { R https://publons.com//researcher/1736805/richard-fedorko/ } \\
\text { Vladimir Vavřečka (D https://orcid.org/0000-0001-6534-3379 } \\
\text { Radovan Bačik (D https://orcid.org/0000-0002-5780-3838 } \\
\text { R https://publons.com/researcher/1736853/radovan-bacik/ } \\
\text { Martin Rigelsky (D https://orcid.org/0000-0003-1427-4689 } \\
\text { R https://publons.com//researcher/1862122/martin-rigelsky/ }\end{array}$ \\
\hline ARTICLE INFO & $\begin{array}{l}\text { L'udovit Nastišin, Richard Fedorko, Vladimir Vavřčka, Radovan Bačik and } \\
\text { Martin Rigelsky (2019). Quantitative study of selected Facebook marketing } \\
\text { communication engagement factors in the optics of different post types. } \\
\text { Innovative Marketing, 15(3), 16-25. doi:10.21511/im.15(3).2019.02 }\end{array}$ \\
\hline DOI & http://dx.doi.org/10.21511/im.15(3).2019.02 \\
\hline RELEASED ON & Wednesday, 31 July 2019 \\
\hline RECEIVED ON & Monday, 17 June 2019 \\
\hline ACCEPTED ON & Monday, 22 July 2019 \\
\hline LICENSE & $\begin{array}{l}(c) E Y \\
\text { This work is licensed under a Creative Commons Attribution } 4.0 \text { International } \\
\text { License }\end{array}$ \\
\hline JOURNAL & "Innovative Marketing " \\
\hline ISSN PRINT & $1814-2427$ \\
\hline ISSN ONLINE & $1816-6326$ \\
\hline PUBLISHER & LLC "Consulting Publishing Company "Business Perspectives" \\
\hline FOUNDER & LLC "Consulting Publishing Company "Business Perspectives" \\
\hline
\end{tabular}

NUMBER OF REFERENCES

40
NUMBER OF FIGURES

0

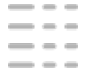

NUMBER OF TABLES

8

(C) The author(s) 2022. This publication is an open access article. 


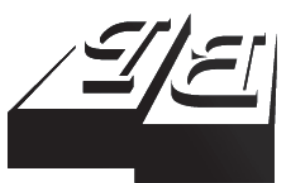

BUSINESS PERSPECTIVES

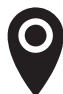

LLC "CPC "Business Perspectives" Hryhorii Skovoroda lane, 10, Sumy, 40022, Ukraine

www.businessperspectives.org

Received on: $17^{\text {th }}$ of June, 2019 Accepted on: $22^{\text {nd }}$ of July, 2019

(C) Ludovít Nastišin,

Richard Fedorko, Vladimír Vavřečka, Martin Rigelský, 2019

Ludovít Nastišin, Ing., Ph.D., Faculty of Management, University of Prešov, Slovakia.

Richard Fedorko, Mgr., Ph.D., Faculty of Management, University of Prešov, Slovakia.

Vladimír Vavřečka, Ing., CSc. Institute of Business and Marketing, University of Business and Law, Czech Republic.

Radovan Bačík, Doc. PhDr., Ph.D., MBA, LL.M., Faculty of Management, University of Prešov, Slovakia.

Martin Rigelský, Mgr., Faculty of Management, University of Prešov, Slovakia.

\section{(c) (1)}

This is an Open Access article, distributed under the terms of the Creative Commons Attribution 4.0 International license, which permits unrestricted re-use, distribution, and reproduction in any medium, provided the original work is properly cited.
Ludovít Nastišin (Slovakia), Richard Fedorko (Slovakia), Vladimír Vavřečka (Czech Republic), Radovan Bačík (Slovakia), Martin Rigelský (Slovakia)

\section{QUANTITATIVE STUDY OF SELECTED FACEBOOK MARKETING COMMUNICATION ENGAGEMENT FACTORS IN THE OPTICS OF DIFFERENT POST TYPES}

\begin{abstract}
The objective of the research was to identify statistically significant differences in selected engagement indicators on Facebook - likes and shares in relation to the different types of content that brands on this platform add to. The analysis was performed on a sample of three global companies from the top 25 most valuable brands in the world and their posts. Using quantitative statistical methods - MANOVA (Multivariate analysis of variance) and Gammes-Howell post hoc test, a total of 1,280 brand posts were analyzed in order to differentiate the liking and sharing of content types. Data collection was carried out in the first half of 2018. The findings pointed to two statistically significant differences that were also interpreted in the discussion of the research. The findings have shown that in case of liking, in two cases out of three, there is a statistically significant difference in terms of the type of content added, when photos came out as those with the greatest potential to get like from Facebook users and fans. At the same time, the same finding appeared in the case of sharing, which is an even stronger form of engagement. Likewise, photos were shown to be the most promising in terms of potential content sharing by Facebook users and fans. The study provided some clues as to where this research should go further and explore the relationship more deeply in view of the more extensive quantitative research, and also the potential qualitative approach. The future research directions include analyzing companies of different types and sizes and also taking into account the contribution from other social networks with the same or similar engagement indicators.
\end{abstract}

\section{Keywords Facebook, engagement, content type, like, share, MANOVA}

\section{JEL Classification M31, M37}

\section{INTRODUCTION}

The impact of social media on a global scale is growing. In spite of recent privacy issues, Facebook is still a fearless leader in this market. Worldwide, it is more than 2.38 billion monthly active users (MAU), an $8 \%$ year-on-year increase (Noyes, 2019). Therefore, from a marketing perspective, it is really important to know how it works behind the scenes. One of the key factors that point to the effectiveness of Facebook branding activities is the engagement rate. Interactions that interfere with it are known as responses, likes, shares, comments, regardless of their nature, whether positive or negative (Huculova, 2018). Mariani et al. (2018), Grace Ji et al. (2017), Stefko et al. (2014) or Srivastava et al. (2018) are also working with these interactions in their research. To sum up, the current article understands the interactions in this sense as any action that the user takes in relation to the brand 
or content. Similarly, Machado et al. (2019) and Belas et al. (2017) define this in their study of the mediation role of customer and brand engagement. This interaction can be managed by the brand to some extent, but the key is that the steps are based on data and metrics, not on impressions (Gavurova et al., 2016). This data approach was also applied by Fatehkia, Kashyap, and Weber (2018) to analyze Facebook data in relation to gender differences in the perception of ads on this platform, and that's where the Facebook platform is perfectly set up because the brand has access to it.

To better address this issue, this study focuses on the liking and sharing factors in the context of the basic content types added to this network - photo, video and text (Maisam \& Mahsa, 2016; Amegbe, 2006). The study can also represent total engagement as a proportion of the sum of comments, likes, shares and mentions versus post reach, as defined by Driskill (2017). It is logical that if we can influence any of these factors, we can also influence the resulting engagement on Facebook to some extent. In this case, the objective is to support it through the right combination of content types that add to the social network via analysis of users in terms of "sharing" and "liking" on selected forms of Facebook contributions.

Findings should help to optimize the activities of a brand regarding content creation and also curation to achieve much better chance to magnify their social media outcome that each brand aims to reach. This analysis novelty lays in its focused and narrowed view on research problems where it presents results based on the data from well-known brands rather than overall statistics of this platform.

\section{LITERATURE REVIEW}

The Facebook social network currently has more than 2 billion active monthly users and more than one billion active daily users (FCI, 2018). Up to one-third of Facebook users communicate with the brand regularly through this network (Chen, 2018). 317,000 status updates, 400 new users, 147,000 photos, and 54,000 links are shared on Facebook every 60 seconds (Smartinsights, 2018). In the analysis of the top 100 global brands by Interbrand, the representation of individual types of content was in favor of photographs (51\%, $N=5,826)$, the second was text posts and links $(35 \%, N=4,120)$, followed by video content $(13 \%, N=1,400)$ and in small representation also individual statuses $(1 \%, N=176)$ (Chen, 2018).

Fu et al. (2017) in their study presented a matrix of psychological stimulus and they were focusing on social capital in which they talk about the stimulus, social capital and content types on social media. Through a two-stage study, they pointed out that different incentives stimulate the sharing of different types of content. They also pointed out that users focusing on different social capital (i.e. factors for the effective functioning of social groups) also have different patterns of sharing. The Swani and Milne research (2017) analyzed
Fortune 500's content strategy focusing on services and goods. The findings from the multivariate multilevel Poisson model have shown that the use of corporate branding is more beneficial in the content on social media related services, while in case of selling goods it is more efficient to use the brand name in the content on social media (Gavurova et al., 2018). According to the Brookes study (2010), photos have an average of $22 \%$ more engagement than videos and $54 \%$ more engagement than text posts. At the same time, videos have $27 \%$ more engagement than text posts. These results suggest that both photos and videos have more potential to hit the audience than a text post. A study by Zell and Moeller (2018) dealing with the potential impact of Facebook status comments, pointed out that there is an association between a number of status comments and the perception of its importance from the perspective of its author. The authors also pointed out that respondents were better able to recall their status with more comments than those with less. In the case of perceived value, Carr, Wohn, and Hayes (2016) found that in the case of their personal perception, likes are considered less supportive than comments, because clicking on Like requires only minimal user effort, thus the process is often automated. Zell and Moeller (2018) add that it is the number of comments, not the likes, which correlates with the 
belief that the Facebook community is more interested in content from the website. They also add that the importance of likes in their research was to predict the potential of posting on Facebook to be positively perceived. A large number of likes can be a social proof signal that indicates the importance of posts to other users.

Mariani, Mura, and Felice (2018) conducted a study of the top 10 most visited countries and their strategic use of Facebook to promote their destination. The study was based on big data obtained from the Facebook pages of these NTOs. The results pointed out that the tactical use of Facebook varied from country to country. The analysis also showed that the engagement is positively influenced by the visual type of content, i.e. photos. In the case of time, there was a positive relationship when publishing content during the weekend, but a negative relationship when publishing content in the evening. Pawsey, Nayeem, and Huang (2018) analyzed the 20 largest Australian and U.K. water distribution companies in terms of their use of Facebook to encourage customer engagement. More than 300,000 responses entered the analysis to almost 17,000 posts between 2010 and 2017. Each year, they experienced a significant increase in the frequency of user content uploading to their website. Despite the trend, however, it turned out that most businesses still add less than one post per day. They also identified shortcomings in the moderation of the Facebook discussions and the under-utilization of the potential of video content.

Research on Facebook's top 100 most valuable world brands from Sitta, Faulkner, and Stern (2018) highlighted a very important finding. It turned out that there is no statistically significant correlation between the size of the brand company and the number of Facebook fans, and that there is no consistent relationship between user engagement and brand size. It is shown that big brands have a limited ability to increase their fan base without paid advertising. This is also due to the inability to create sufficiently targeted and personal content, which is logical according to the size of the companies. Kim and Yang (2017) in their study found that a different type of content led to a different type of behavior. Specifically, they found that visual content led to likes, rational and interactive content led to comments, sensory, visual and rational content led to sharing. They pointed out that likes are based on emotions, comments are based on cognitive aspects and sharing is either effective, cognitive, or a combination of both.

Recent studies, such as Ananda et al. (2019), also addressed this area in identifying sources of eWOM generation in relation to social media engagement for fashion brands. Consumer engagement in relation to social currency in online reviews was analyzed by Kesgin and Murthy (2019), and they found that this relationship has a positive impact on the intent of re-visiting the brand or website's account. Dolan, Seo, and Kemper (2019) presented an empirical study of social media complaints on large Australian airlines. Stefko et al. (2015) presented an empirical study analyzing the influence of the up-to-date nature of website content in terms of reputation management. Busalim et al. (2019) published an in-depth analysis of consumer engagement studies in the context of s-commerce, highlighting important factors that play a key role. Hsu (2019) also declared a statistical significance of trust in the brand while mediating further interaction with both the customer and the social media environment. Kumar et al. (2019) engaged in social engagement platforms on social commerce platforms where they worked with Navigational Clickstream Data. The nature of user engagement in relation to communication in the political spectrum of parliamentary elections in 2013 and 2015 in the Czech Republic and Poland was examined by Stetka, Surowiec, and Mazak (2019), who pointed out the significant impact of gender factor on the nature of the post. The social media news management was also compared by Chan, Chen, and Lee (2019) on a sample of six countries, highlighting the factors supporting engagement and viral spread of these posts. The issue of consumer engagement in virtual space was also addressed by Mirbagheri and Najmi (2019), Shugars and Beauchamp (2019), Aydin (2019), Lizbetinova et al. (2019) and Martin-Consuegra et al. (2019).

\section{METHOD}

The presented research can be characterized from the point of view of scientific focus as intradisciplinary, from the point of view of outputs as ap- 
plied, from the perspective of data collection as secondary and from the perspective of analytical processing as relational research. The chosen methodological approach refers to the research by Zell and Moeller (2018) and their analysis of the comments under the post; to the analysis of the perceived value of likes versus comments of Carr, Wohn, and Hayes (2016); also to an extensive analysis of Facebook engagement by Pawsey, Naye, and Huang (2018) and examining the relevance of fan base size to the resulting engagement from Sitta, Faulkner, and Stern (2018).

The primary objective of this paper is to analyze the interaction of users in terms of "sharing" and "liking" on selected forms of Facebook contributions, i.e. text, photo and video contributions, through the in-depth analysis of the difference. Based on this objective, the study focuses on the research question:

Is there a difference in "likes" and "shares" between the different forms of Facebook posts?

The main hypothesis is as follows: There is a difference in "likes" and "shares" between the selected forms of Facebook posts.

As it can be assumed, sharing and liking are procedures that are often performed together. Based on this assumption, MANOVA (Multivariate analysis of variance) will be used to analyze the homogeneity of the procedures. Application of the MANOVA method requires the congruence of several conditions such as normality, multicollinearity, non-significant outliers, etc. Verification of suitability for use, i.e. demonstration of compliance will be shown in the analytical section of the study.

Multivariate analysis of variance (MANOVA) is an extension of the analysis of variance (ANOVA) and a technique where more than two variables are used within independent variables - factors, and two and more are used within dependent variables, as they have to be in a continuous distribution of a random variable, therefore they have to be metric data (Hair et al., 2014). As MANOVA determines only the demonstrable existence of differences, a Gammes-Howell post hoc test was used to determine the particular difference.
The subject analysis understands the data as static, which is, to some extent, a limitation of the method, as it could be expected that other variables (constructs) could also influence the variability. However, it is assumed that these variables are the same for all forms, and thus do not significantly interfere with the compared outputs in the dimension of their diversity. The most prominent element that could affect the outputs is time, so the frequency of activities (like, share) is not constant throughout the existence of the contribution, thus with the increasing time a decreasing frequency of the "like" or "share" could be expected. Also, it can be assumed that the inconsistency in question will not differ between the companies, so the analysis is not expected to be distorted by analogy.

When collecting data, the study focused on the contributions of three world-class companies, each focusing on a different type of business. They were a major IT company (Microsoft), a footwear company (Nike) and a large e-shop with clothing and fashion accessories (Zara). However, all companies were among the top 25 most valuable brands in the world, according to Interbrand (2017). Specifying companies with regard to the objective of the contribution is irrelevant. The criterion was a minimum of 30 monthly posts during the 6-month review period from the beginning of 2018. The study only worked with posts on the official social media sites of the brand that are verified by this platform. It did not work with fanpages. 1,280 entries entered the analysis, with selected parameters recorded for each one: content type, number of likes, number of shares. The analysis was conducted during the first half of 2018 .

\section{RESULTS}

In the following section, using descriptive and relational research tools, all the elements relevant to the analysis resulting from the research question will be described, i.e. the objective of the research will be met. This part is divided into three parts. The first one statistically describes the variables that belong to the research, the second will be devoted to the proof of the suitability of the MANOVA method and the third part deals with the exact position resulting from the main objective of the study. 


\subsection{Statistical description of variables}

An independent variable, type of contribution, as well as two dependent variables, the number of likes and shares enter the research. The frequency of each content type category was as follows: photo $32.81 \%(N-420)$, video $38.28 \%(N-491)$ and text $28.9 \%(N-369)$. Individual types of contributions are represented approximately proportionally. Videos are the most numerous, followed by text posts and photos. As mentioned, this polyatomic nominal variable enters into the investigation as independent. The basic descriptive analysis of dependent variables is shown in Table 1.

Table 1. Description of variables

\begin{tabular}{|c|c|c|c|}
\hline & & Likes & Shares \\
\hline \multirow{2}{*}{ N } & Valid & 1280 & 1280 \\
\hline & Missing & 0 & 0 \\
\hline Mean & - & 538.680 & 36.023 \\
\hline Median & - & 199.000 & 29.000 \\
\hline Std. deviation & - & 669.9488 & 26.3060 \\
\hline Minimum & - & 45.0 & 5.0 \\
\hline Maximum & - & 2614.0 & 118.0 \\
\hline \multirow{3}{*}{ Percentiles } & 25 & 124.250 & 17.000 \\
\hline & 50 & 199.000 & 29.000 \\
\hline & 75 & 769.750 & 46.000 \\
\hline
\end{tabular}

The variables reflect the number of activities and thus the number of likes and shares. The research sample consists of 1,280 observations. If one focuses on average in the like, the median is relatively high. Already from this table, it can be concluded that liking posts are more frequent than sharing them. The following part of the study is devoted to evidence of the suitability of the intended MANOVA method.

\subsection{Verifying the conditions of MANOVA method}

The following part of the study will be devoted to the description of proving the conditions necessary for the implementation of the planned analysis. One of the conditions for applying the MANOVA method is the normal distribution of dependent variables in all categories of the independent variable. Table 2 shows the normality test outputs.
Table 2. Normality test

\begin{tabular}{|c|c|c|c|c|c|}
\hline \multicolumn{2}{|c|}{ Content type } & \multicolumn{2}{|c|}{$\begin{array}{c}\text { Kolmogorov- } \\
\text { Smirnov }\end{array}$} & \multicolumn{2}{|c|}{ Shapiro-Wilk } \\
\hline & & Static & Sig. & Static & Sig. \\
\hline \multirow{3}{*}{ Likes } & Foto & .079 & $.200 *$ & .964 & .207 \\
\hline & Video & .134 & .028 & .970 & .238 \\
\hline & Text & .151 & .032 & .928 & .020 \\
\hline \multirow{3}{*}{ Shares } & Foto & .139 & .040 & .935 & .019 \\
\hline & Video & .079 & $.200^{*}$ & .969 & .212 \\
\hline & Text & .140 & .065 & .915 & .008 \\
\hline
\end{tabular}

The normality is fully accepted if $p$, the asymptotic significance is greater than 0.05 . As can be seen, this assumption has been confirmed in most cases. Table 2 contains the outputs of the KolmogorovSmirnov test and the Shapiro-Wilk test, as the data are fluctuating around 500 observations. From the outputs, one can see that data are acceptable in terms of normality.

Table 3. Multicollinearity test

\begin{tabular}{c|c|c}
\hline Correlations & Shares \\
\hline \multirow{4}{*}{ Likes } & Pearson correlation & 0.722 \\
& Sig. (2-tailed) & 0.000 \\
& N & 1280 \\
\hline
\end{tabular}

The second very important condition is the condition of multicollinearity. This condition was verified by means of the traditional correlation, where one can see the correlation coefficient Pearson $r$ defines the output 0.722 (see Table 3). The condition of multicollinearity would not be met if the correlation coefficient was higher than 0.8 , which is not the case. This condition can be considered fulfilled.

Table 4. Homogeneity of covariance matrices. Box's test of equality of covariance matrices

\begin{tabular}{l|c}
\hline Box's M & 294.818 \\
\hdashline F & 47.987 \\
\hline Sig. & .000 \\
\hline
\end{tabular}

The homogeneity of covariance matrices is verified by Table 4, where the last row shows that the asymptotic significance is less than 0.05 , which is very likely to demonstrate a significant difference in matrices. From the application point of view, it is considered as a minor problem, but it will be solved by using a different kind of test to determine the difference. In a later analysis, the study will incline to the Pillai's trace test. 
Table 5. Levene's test.

Levene's test of equality of error variances

\begin{tabular}{l|c|c}
\hline & $\mathbf{F}$ & Sig. \\
\hline Likes & 841.89 & .000 \\
\hline Shares & 222.58 & .000 \\
\hline
\end{tabular}

The study also verifies the homogeneity of the variances. Table 5, the last column, shows a significant difference. The study also considers this high-probability output as a problem, but the GammesHowell post hoc test will be used as the solution.

A very important condition is the absence of multivariate extremes. This condition was verified using the Mahalanobis distance, the critical value for two dependent variables is 13.82 . The maximum of the measured value is 12.8365 , thus this condition is considered fulfilled as well.

Previous studies have analyzed the suitability of applying the MANOVA method, which has been pointed out that can be applied to the data. The next part of the study points out the exact outcomes leading to the difference between liking and sharing the different types of posts on Facebook.

\subsection{Exact outcomes of the difference}

Table 6 shows the significance of the multivariate model. Statistical significance was verified by the Pillai's trace method, since the equation of covariant matrices was not confirmed.

Table 7. Statistical significance of differences
Table 6. Multivariate tests

\begin{tabular}{c|c|c|c|c}
\hline Effect & & Value & F & Sig. \\
\hline Content-type & Pillai's trace & .665 & 31.166 & .000 \\
\hline
\end{tabular}

The most important value in terms of the significance of the multivariate model is given in the last column of Table 6 . As one can see, the value of asymptotic significance is zero to three decimal places, thus most likely, one should talk about the statistically significant variation in the frequency of liking and sharing photos, videos and texts. Table 6 , however, tells us only about the significant difference in the multivariate context. Based on the above output, we cannot assess the particular difference in liking and sharing. This information will be found in the next paragraph.

Table 7 precisely determined the statistical significance of the differences between the different types of contributions in the dimension of liking and sharing. The focus is primarily on the Content-type line. This line shows the likes and shares, and their asymptotic significance is shown in the last column. As one can see, this value is zero to three decimal places, thus it is worth talking about the significant variation in the frequency of liking between photos, video and text posts. We are also talking about the significant difference in sharing photos, videos and text posts. Table 7 and the values shown there determine the difference as significant, but they do not offer information on which type of difference is significant and vice

\begin{tabular}{|c|c|c|c|c|c|}
\hline \multicolumn{2}{|c|}{ Source } & \multirow{2}{*}{$\frac{\text { Type III sum of squares }}{364713329.400}$} & \multirow{2}{*}{$\frac{\text { Mean square }}{18235666.467}$} & \multirow{2}{*}{$\frac{\mathbf{F}}{111.029}$} & \multirow{2}{*}{$\frac{\text { Sig. }}{.000}$} \\
\hline & Likes & & & & \\
\hline 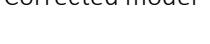 & Shares & 268361.700 & 13418.085 & 27.474 & .000 \\
\hline \multirow{2}{*}{ Intercept } & Likes & 374297253.990 & 37429725.399 & 227.894 & .000 \\
\hline & Shares & 1682054.350 & 168205.435 & 344.408 & .000 \\
\hline \multirow{2}{*}{ Content-type } & Likes & 364713329.350 & 18235666.467 & 111.029 & .000 \\
\hline & Shares & 268361.700 & 13418.085 & 27.474 & .000 \\
\hline \multirow{2}{*}{ Error } & Likes & 205302509.320 & 164242.007 & - & - \\
\hline & Shares & 610487.600 & 488.390 & - & - \\
\hline \multirow{2}{*}{ Total } & Likes & 941440870.000 & & \multirow{4}{*}{-} & \\
\hline & Shares & 2539890.000 & & & \\
\hline \multirow{2}{*}{ Corrected total } & Likes & 570015830.000 & & & \\
\hline & Shares & 878849.300 & & & \\
\hline
\end{tabular}


Table 8. Paired comparison of post types

\begin{tabular}{|c|c|c|c|c|c|c|c|}
\hline \multirow{2}{*}{\multicolumn{2}{|c|}{ Dependent variable }} & & \multirow{3}{*}{$\begin{array}{c}\text { Mean difference } \\
\text { (I-J) } \\
1134.36\end{array}$} & \multirow{3}{*}{$\begin{array}{c}\text { Std. error } \\
108.5110\end{array}$} & \multirow{3}{*}{$\begin{array}{l}\text { Sig. } \\
.000\end{array}$} & \multicolumn{2}{|c|}{ 95\% Confidence interval } \\
\hline & & & & & & Lower bound & Upper bound \\
\hline \multirow{6}{*}{ Likes } & \multirow{2}{*}{ Foto } & Video & & & & 870.640 & 1398.074 \\
\hline & & Text & 1140.15 & 108.8030 & .000 & 875.824 & 1404.473 \\
\hline & \multirow{2}{*}{ Video } & Foto & -1134.36 & 108.5110 & .000 & -1398.074 & -870.640 \\
\hline & & Text & 5.792 & 15.3802 & .925 & -31.019 & 42.602 \\
\hline & \multirow{2}{*}{ Text } & Foto & -1140.15 & 108.8030 & .000 & -1404.473 & -875.824 \\
\hline & & Video & -5.792 & 15.3802 & .925 & -42.602 & 31.019 \\
\hline \multirow{6}{*}{ Shares } & \multirow{2}{*}{ Foto } & Video & 33.156 & 5.1922 & .000 & 20.617 & 45.696 \\
\hline & & Text & 26.516 & 5.8232 & .000 & 12.563 & 40.469 \\
\hline & \multirow{2}{*}{ Video } & Foto & -33.156 & 5.1922 & .000 & -45.696 & -20.617 \\
\hline & & Text & -6.640 & 3.5245 & .153 & -15.126 & 1.846 \\
\hline & \multirow{2}{*}{ Text } & Foto & -26.516 & 5.8232 & .000 & -40.469 & -12.563 \\
\hline & & Video & 6.640 & 3.5245 & .153 & -1.846 & 15.126 \\
\hline
\end{tabular}

versa, where the difference is insignificant, where differences are random.

Table 8 shows a paired comparison of the different types of contributions in the dimension of likes and shares. These differences are supported by the Games-Howell posthoc test, which is useful in analyzing differences with unsatisfied homogeneity of variance.

The focus is on the part of the table which deals with likes. As one can see, between the post in the form of photo and video, there is a significant difference and it can be found out that the photo was "liked" more often than the video when analyzing the difference in averages. Differences were also seen in the comparison of photo and text in favor of the photo. There was no significant difference between video and text. If to focus on shares, one can see that in the area of contribution types, the paired analysis was similar to the one with the likes.

Significant differences were seen only between photos and videos, where the photo is, on average, more widely shared than the video. Even when comparing photos and texts, one can see a significant difference in which it can be argued that photo posts are shared more often than texts. There was no significant difference between the video and text posts.

\section{DISCUSSION}

The previous section was devoted to an in-depth analysis of the variation in the frequency of lik- ing and sharing depending on the type of contribution. In both forms of interaction (liking, sharing), the greatest differences in case of photos were shown. If one focuses on posting, average values show that photo contents are shared most often. There are significant differences between photos and other types. The second most common sharing can be seen in the case of texts and videos. There were no significant differences between video and text sharing. The situation in case of liking is similar to sharing, but the average values show that photos are the most popular. There are significant differences between photos and other types. The second most frequent liking can be seen in the case of videos, and it is followed by texts.

The findings of the current study are also confirmed by the findings of Mariani, Mura, and Felice (2018), who pointed out in their research that engagement is positively influenced by the visual type of content, especially by photos. The divergence of results for each type of content points to a potential parallel with the research by Kim and Yang (2017), who found that a different type of content led to a different type of behavior. In this case, however, it would require further investigation and a shift to the qualitative spectrum of the nature of the contributions.

These results are somewhat supported by Sprout social's statistical findings (Chen, 2018), which cumulatively point out that more than half of the added content is in the form of photos and about a third in the form of videos. Thus, one can say that large companies are paying atten- 
tion to their content strategy in the Facebook environment and are trying to invest efforts in content types that are most likely to get their audience's attention and improve the engagement rate by these factors.

There is also a parallel with the study by $\mathrm{Fu}$ et al. (2017), which pointed out that different psychological stimuli affect different patterns of sharing and response to the contribution. The nature of the contribution and its ability to carry the emotion in itself, thus contributing to a number of user's senses, play an important role. Textual contributions are just a rational perception and often require a longer time to understand the message. On the contrary, photos and videos can almost instantly affect the emotional level in the right processing, leading the user to a different pattern of sharing and responding to the post. Most likely, this factor has also supported the findings of the current research.

The most important practical implications rooting from this research are to focus as much as possible on the content of visual nature (photos, videos) in case of time investment since those are most likely to resonate with the users and brand followers. It does not mean omitting other types completely because a brand needs to look authentic. Visual content should just play the primary role in the brand's social media calendar. Great importance should be also placed on tracking and measuring all activities and tailoring the content to fit with your followers as much as possible. Blindly following the rule to post the visual content and not taking into account what it actually shows and how it is shown is dangerous. Tracking performance can prevent it from happening.

This research focused on the activities of the world's largest brands on Facebook. In the case of managerial implications, the limiting fact is that the amount of financial and human capital that these large companies invest in social media is incomparable with small and medium-sized enterprises. However, it is equally important to bear in mind the findings of Sitta, Faulkner, and Stern (2018) that there is no statistically significant correlation between the size of the brand and the number of Facebook fans, and that there is no consistent relationship between user engagement and brand size. With the right steps and taking into account the characteristics of the market in which the company operates, a social media manager can achieve several times bigger results than large companies when guided by practical implications. Because, as it has been already mentioned, the number of fans is just one of the factors that are entering success on social media. Future research will focus directly on other types and the sizes of companies. The ability to extend the applicability of these results is also seen in taking into account, besides Facebook, contributions from other social networks, where likes and shares are also indicators of engagement. Especially in the Instagram, YouTube and Twitter platforms, we have the ability to take into account the particular companies analyzed and the market in which they operate, as they also have specific features and their insight can distort the results.

\section{CONCLUSION}

Growing impact of the social media on various aspects of businesses, the need for personal interactions in communication with the users, and the demand for immediate response or overwhelming amount of the social media content - all these aspects bring attention to the knowledge of how to succeed in this virtual environment. Regarding this, the current study analyzed the interaction of users in terms of "sharing" and "liking" on the selected forms of Facebook contributions through the in-depth analysis of the difference. The content-type "photos" were presented as the one with the greatest potential to perform in the case of acquiring likes and in the case of acquiring shares, which are considered to be an even stronger contributor to overall engagement. There is a space for deepening these findings via analyzing the different company types and sizes or considering also other social media that can play a significant role in the overall brand performance in this virtual environment. 


\section{ACKNOWLEDGMENT}

This article is one of the partial outputs under the scientific research grant VEGA 1/0789/17 - Research of e-commerce with relation to dominant marketing practices and important characteristics of consumer behavior while using mobile device platforms, and VEGA 1/0609/19 - Research on the development of electronic and mobile commerce in the aspect of the impact of modern technologies and mobile communication platforms on consumer behavior and consumer preferences.

\section{REFERENCES}

1. Amegbe, H. (2016). Internal Branding and the Competitive Performance of Private Universities in Ghana. Journal of Competitiveness, 8(3), 2237. https://doi.org/10.7441/ joc.2016.03.02

2. Ananda, A. S., HernandezGarcia, A., Acquila-Natale, E., \& Lamberti, L. (2019). What makes fashion consumers "click"? Generation of eWoM engagement in social media. Asia Pacific Journal of Marketing and Logistics, 31(2), 398-418. http://dx.doi.org/10.1108/ APJML-03-2018-0115

3. Aydin, G. (2019). Social media engagement and organic post effectiveness: A roadmap for increasing the effectiveness of social media use in hospitality industry. Jounal of Hospitality Marketing \& Management, 1-21. https://doi.org/10.1080/19368623. 2019.1588824

4. Belas, J., Gavurova, B., Schonfeld, J., Zvarikova, K., \& Kacerauskas, T. (2017). Social and economic factors affecting the entrepreneurial intention of university students. Transformations in Business and Economics, 16(3), 220239. Retrieved from https:// www.researchgate.net/ publication/322438421_social_and_economic_factors_affecting_the_entrepreneurial_intention_of_university_students

5. Brookes, E. J. (2010). The anatomy of a Facebook post. Study on post performance by type, day of week, and time of day. Vitrue-Oracle. Retrieved from http://www. vitrue.com/wpcontent/themes/ Vitrue-3.0/white-papers/anatomy_ of_fb_wp.pdf
6. Busalim, A. H., Hussin, A. C., \& Iahad, N. A. (2019). Factors influencing customer engagement in social commerce websites: a systematic literature review. Journal of Theoretical and Applied Electronic Commerce Research, 14(2), 1-14. Retrieved from https://dl.acm.org/citation. cfm?id=3289219

7. Carr, C. T., Wohn, D. Y., \& Hayes, R. A. (2016). As social support: Relational closeness, automaticity, and interpreting social support from paralinguistic digital affordances in social media. Computers in Human Behavior, 62, 385-393. http://dx.doi. org/10.1016/j.chb.2016.03.087

8. Dolan, R., Seo, Y., \& Kemper, J. (2019). Complaining practices on social media in tourism: A value co-creation and co-destruction perspective. Tourism Management, 73, 35-45. https://doi.org/10.1016/j. tourman.2019.01.017

9. Driskill, J. (2017). Facebook Egnagement Rate Calculator (The Online Advertising Guide). Retrieved from https://theonlineadvertisingguide.com/ad-calculators/facebook-engagement-ratecalculator/

10. Facebook company info. (2018). Retrieved from https://newsroom. fb.com/company-info/

11. Fatehkia, M., Kashyap, R., \& Weber, I. (2018). Using Facebook ad data to track the global digital gender gap. World Development, 107, 189-209. https://doi.org/10.1016/j.worlddev.2018.03.007

12. Fu, P.-W., Wu, C.-C., \& Cho, Y.-J. (2017). What makes users share content on Facebook?
Compatibility among psychological incentive, social capital focus, and content type. Computers in Human Behavior, 67, 23-32. https://doi.org/10.1016/j. chb.2016.10.010

13. Gavurova, B., Bacik, R., Fedorko, R., \& Nastisin, L. (2018). The customer's brand experience in the light of selected performance indicators in the social media environment. Journal of Competitiveness, 10(2), 7284. https://doi.org/10.7441/ joc. 2018.02 .05

14. Gavurova, B., Vagasova, T., \& Kovac, V. (2016, June 27-28). Competitiveness Assessment of Slovak Republic Regions. European Financial System 2016. In J. Krajicek, J. Nesleha, \& K. Urbanovsky (Eds.), 13th International Scientific Conference of the European Financial Systems (pp. 175+). Brno, Czech Republic.

15. Hair, J. F. Jr., Black, W. C., Babin, B. J., \& Anderson, R. E. (2014). Multivariate Data Analysis (7th ed.). Pearson Education Limited, Harlow, United Kingdom.

16. Hsu, L. C. (2019). Building Brand-Fan Relationships in Social Commerce Contexts: Mediators of Online Brand Relationships. Journal of Theoretical and Applied Electronic Commerce Research, 14(2), 106-123. http:// dx.doi.org/10.4067/S071818762019000200109

17. Huculová, E. (2018). Porovnanie vybraných metodologických prístupov HTA na národnej úrovni a na úrovni nemocníc. Exclusive journal: economy and society and environment. Prešov: eXclusive marketing, 6(4), 53-59. 
18. Chan, M., Chen, H. T., \& Lee, F. L. F. (2019). Examining the Roles of Political Social Network and Internal Efficacy on Social Media News Engagement: A Comparative Study of Six Asian Countries. International Journal of Press-Politics, 24(2), 127-145. https://doi.org/1$0.1177 \% 2 \mathrm{~F} 1940161218814480$

19. Chen, J. (2018). 15 Facebook stats every marketer should know for 2019. Retrieved from https://sproutsocial. com/insights/facebook-stats-formarketers

20. Ji, Y. G., Li, C., North, M., \& Liu, J. (2017). Staking reputation on stakeholders: How does stakeholders' Facebook engagement help or ruin a company's reputation? Public Relations Review, 43(1), 201-210. https://doi.org/10.1016/j. pubrev.2016.12.004

21. Kesgin, M., \& Murthy, R. S. (2019). Consumer engagement: the role of social currency in online reviews. Service Industries Journal, 39(7-8), 609-636. https://doi.org/10.1080/02 642069.2018.1553237

22. Kim, C., \& Yang, S. U. (2017). Like, Comment, and Share on Facebook: How each behavior differs from the other. Public Relations Review, 43(2), 441-449. https://doi.org/10.1016/j. pubrev.2017.02.006

23. Kumar, A., Salo, J., \& Li, H. X. (2019). Stages of User Engagement on Social Commerce Platforms: Analysis with the Navigational Clickstream Data. International Journal of Electronic Commerce, 23(2), 179-211. Retrieved from https://researchportal.helsinki.fi/ en/publications/stages-of-userengagement-on-social-commerceplatforms-analysis-w

24. Lizbetinova, L., Starchon, P., Lorincova, S., Weberova, D., \& Prusa, P. (2019). Application of Cluster Analysis in Marketing Communications in Small and Medium-Sized Enterprises: An Empirical Study in the Slovak Republic. Sustainability, 11(8), 2302. https://doi.org/10.3390/su11082302

25. Machado, J. C., Vacas-de-Carvalho, L., Azar, S. L., Andre, A. R., \& Santos, B. P. (2019). Brand gender and consumer-based brand equity on Facebook: The mediating role of consumer-brand engagement and brand love. Journal of Business Research, 96, 376-385. https://doi. org/10.1016/j.jbusres.2018.07.016

26. Maisam, S., \& Mahsa, R. (2016). Positive Word of Mouth Marketing: Explaining the Roles of Value Congruity and Brand Love. Journal of Competitiveness, 8(1), 19-37. https://doi.org/10.7441/ joc.2016.01.02

27. Mariani, M., Mura, M., \& Felice, M. (2018). The Determinants of Facebook social engagement for national tourism organizations Facebook pages: A quantitative approach. Journal of Destination Marketing \& Management, 8, 312-325. https://doi.org/10.1016/j. jdmm.2017.06.003

28. Martin-Consuegra, D., Diaz, E., Gomez, M., \& Molina, A. (2019) Examining consumer luxury brand-related behavior intentions in a social media context: The moderating role of hedonic and utilitarian motivations. Physiology \& Behavior, 200, 104-110. https://doi. org/10.1016/j.physbeh.2018.03.028

29. Mirbagheri, S., \& Najmi, M. (2019). Consumers' engagement with social media activation campaigns: Construct conceptualization and scale development. Psychology \& Marketing, 36(4), 376-394. https:// doi.org/10.1002/mar.21185

30. Noyes, D. (2019). Facebook statistic updated April 2019. Zephoria. Retrieved from https://zephoria. com/top-15-valuable-facebookstatistics/

31. Pawsey, N., Nayeem, T., \& Huang, X. (2018). Use of Facebook to Engage Water Customers: A comprehensive study of current U.K. and Australian practices and trends. Journal of Environmental Management, 228, 517-528. https://doi.org/10.1016/j. jenvman.2018.08.063

32. Shugars, S., \& Beauchamp, N. (2019). Why Keep Arguing? Predicting Engagement in Political Conversations Online. Sage Open, 9(1). https://doi.org/ $10.1177 \% 2 F 2158244019828850$

33. Sitta, D., Faulkner, M., \& Stern, P. (2018). What can the brand manager expect from Facebook? Australasian Marketing
Journal, 26(1), 17-22. https://doi. org/10.1016/j.ausmj.2018.01.001

34. Smart insights. (2018). What happens online in 60 seconds? Retrieved from https://www. smartinsights.com/internet-marketing-statistics/happens-online60 -seconds/

35. Srivastava, J., Saks, J., Weed, A. J., \& Atkins, A. (2018). Engaging audiences on social media: Identify interrelationships between message factors and user engagement on the American Cancer Society's Facebook page. Telematics and Informatics, 35(7), 18321844. https://doi.org/10.1016/j. tele.2018.05.011

36. Stefko, R., Bacik, R., \& Fedorko, I. (2014). Facebook Content Analysis of Banks Operating on Slovak Market. Polish Journal of Management Studies, 10(1), 145-152. Retrieved from https://econpapers. repec.org/article/pczjournl/v_3a10_3ay_3a2014_3ai_3a1_3ap_ 3a145-152.htm

37. Stefko, R., Fedorko, I., Bacik, R., \& Fedorko, R. (2015). An Analysis of Perceived Topicality of Website Content Influence in Terms of Reputation Management. Polish Journal of Management Studies, 12(1), 177-185. Retrieved from https://www.researchgate.net/ publication/290456199_An_analysis_of_perceived_topicality_of_website_content_influence_in_terms_ of_reputation_management

38. Stetka, V., Surowiec, P., \& Mazak, J. (2019). Facebook as an instrument of election campaigning and voters' engagement: Comparing Czechia and Poland. European Journal of Communication, 34(2), 121-141. https://doi.org /10.1177\%2F0267323118810884

39. Swani, K., \& Milne, G. R. (2017). Evaluating Facebook brand content popularity for service versus goods offerings. Journal of Business Research, 79(1), 123-133. https://doi. org/10.1016/j.jbusres.2017.06.003

40. Zell, A. L., \& Moeller, L. (2018). Are you happy for me ... on Facebook? The potential importance of "likes" and comments. Computers in Human Bahavior, 78, 26-33. https:// doi.org/10.1016/j.chb.2017.08.050 